\title{
ILLICIT JUSTICE: Aspirational-Strategic Subjects and the Political Economy of Domestic Violence Law in India
}

\author{
Poulami Roychowdhury
}

\begin{abstract}
Criminal cases against domestic violence in India frequently result in unlawful "compromises" where litigants breach legal procedure and negotiate out-of-court settlements. Using ethnographic and interview data, this Article analyzes how legal cases become extralegal settlements. I argue that India's legal environment engenders an "aspirational-strategic" legal consciousness among survivors, who simultaneously believe they deserve what the law promises while distrusting legal procedure and law enforcement personnel. Their bifurcated vision of the law leads them to negotiate illicit settlements. These findings indicate that expansions in legal rights can have contradictory effects on rule of law. Depending on the political economy of the legal institutional environment, citizens may respond to rights by simultaneously adopting new norms while ignoring legal rules and procedure.
\end{abstract}

\section{INTRODUCTION}

Far greater numbers of women report domestic violence in India today than they did in the past. Between 2006 and 2016, criminal cases registered under Section 498A of the Indian Penal Code (IPC) increased by 75 percent (National Crime Records Bureau 2017). ${ }^{1}$ The Indian Code of Criminal Procedure decrees it unlawful to withdraw a 498A complaint once it has been filed or reach a settlement outside the criminal justice system. Yet, a significant number of these cases are resolved out of court, in what has been termed "compromises" by state officials, mainstream media outlets, and academics. Of the 91,810 cases that went to trial in 2016, 8,437 cases (9.2 percent) were compromised (National Crime Records Bureau 2017). Ethnographic and interview-based research studies indicate that these official numbers grossly settlements (Burton et al. 2000; Dave and Solanki 2000).

Poulami Roychowdhury is Assistant Professor of Sociology at McGill University. Her research focuses on gender, politics, and governance. Roychowdhury has written about the consequences of feminist mobilization around sexual violence in India, the changing character of women's citizenship rights, masculinity and labor organizing in New York, and international media coverage of sexual violence. The research for this Article was funded through grants from the National Science Foundation and the Fulbright-Nehru. Dr. Roychowdhury can be contacted at poulami.roychowdhury@mcgill.ca.

1. Cases registered under Section 498A rose from 63,128 in 2006 to 110,378 cases in 2016. Reporting rates increased even as aggregate rates of violence fell over the same time period (International Institute for Population Sciences 2016). Results from the National Family Health Survey (nationally representative survey of 79,729 women) indicates that 37.2 percent of ever-married women between the ages of $15-45$ years old had experienced some form of domestic violence in 2006, whereas that number dropped to 31 percent in 2016. 
Compromises highlight the challenges involved in expanding women's rights against violence. They also raise broader questions about the relationship between rights and rule of law. For feminist activists and legal scholars in India, they highlight the law's failure to ensure speedy and fair justice to vulnerable women (Agnes 2005). In this line of thinking, survivors compromise because they are either intimidated by their abusers or lack the time and financial resources to fight lengthy trials (Baxi 2010; Basu 2015). Meanwhile, family organizations and men's rights activists believe compromised cases prove that women are misusing legal protections: bringing false allegations against their husbands in the hopes of extracting concessions outside the criminal justice system (Kishwar 2003). Conservative policymakers have gone so far as to use the incidence of compromised cases to fight for a rollback in legal protections (Koshyari 2011). While approaching the issue from very different standpoints, women's rights activists and conservative pro-family advocates share a common concern: by expanding women's rights against violence, Indian legislators may have undermined the rule of law.

This Article considers the following question: How and why do criminal cases against domestic violence become "compromised"? Compromised cases are puzzling not necessarily because women are seeking solutions outside criminal law. Due to a host of social, financial, and emotional barriers, women all around the world frequently avoid the state when experiencing domestic abuse (World Health Organization 2013). Working-class and minority women are especially likely to steer clear of criminal law, because it provides a vehicle for the state to enter marginalized communities and impose punishments (Coker 2001; Suk 2006). In India, local communities have a long history of resolving domestic disputes through mediation and arbitration (Subramanian 2014). More intriguing is the fact that increasing numbers of women are registering cases even while a sizeable number of cases result in extralegal outcomes.

Compromised cases combine public forms of ordering (official legal cases) with private ordering (extralegal and illegal forms of dispute processing). Private ordering emerges from various sources, including systems of meaning that lie outside the law but have cultural resonance, such as an "ethics of care" (Ranasinghe 2014) or in "market communities" that are not completely controlled by the state (Fisher 2008).

Gender and legal scholars have argued that women compromise with their abusers because they are surrounded by cultures of "reconciliation" that are fundamentally sexist (Lazarus-Black 2007). India-specific research affirms this basic point. Women who make legal claims against domestic violence face social sanction both from friends and family and discrimination within the criminal justice system (Agnes 2005; Kannabiran 2005; Jaising 2007). Police officers silence complaints (Bhattacharya 2009). Judges believe "good victims" withstand abuse without complaining (Lodhia 2009; Sen 2010; Basu 2012).

While the aforementioned literature captures one reason why survivors settle out-of-court, this Article identifies a different mechanism: the political economy of domestic violence law and how it shapes survivors' legal consciousness. To analyze the evolution of "compromises," I use data gathered through twenty-two months of participant observation of domestic violence cases and thirty in-depth interviews with survivors in West Bengal, India. This qualitative approach allowed me to understand the social processes undergirding compromises, processes that are not always visible in large-scale surveys. 
Survivors traversed what I characterize as a "stalled legal environment," where political pressure for rights outstripped the state's ability to enforce legal protections. A range of civil society organizations helped women advance legal claims and taught them how to subvert legal procedure. Meanwhile, the criminal justice system failed to ensure rights but also looked the other way when survivors used cases to extract concessions outside the law. By interacting with this environment, survivors developed an "aspirational-strategic" legal consciousness. They came to believe they deserved what the law promised, a life free of violence. Simultaneously, they learned to violate legal rules and procedure, using legal cases as bargaining chips. Their bifurcated engagement with the law ensured that even as the numbers of registered reports grew, formal cases continued to be resolved through extralegal settlements.

My findings underscore three larger points. First, gender bias is not the only, or necessarily always the most important, social force guiding women's actions. The survivors I talked to encountered discrimination from law enforcement personnel and from society at large. And the discrimination they faced did constrain their opportunities and abilities to access legal rights. But survivors navigated a complex, and at times contradictory terrain. Be it in the form of an NGO that pushed them toward the law or the police who ignored illicit behaviors around legal cases, these alternate institutional processes enabled specific forms of legal engagement.

Second, from the perspective of women who are using legal statutes to address violence, "compromise" may not be the best way to think about legal outcomes. To describe the end product of their legal engagements, survivors used the term mìmānsā, which means "compromise," "settlement," and "solution" all at the same time in Bengali. This term indicates that the legal process provides something more complex than the official discourse would belie. Survivors are not passive victims of a sexist legal system. They proactively make use of laws and embrace illicit tactics to secure otherwise unattainable resources.

Third, expansions in legal rights can have contradictory effects on rule of law. The degree to which rule of law is strengthened or undermined will partially depend on the political economy of the legal institutional environment and how it influences citizen behavior. When political pressure for rights is robust, yet criminal justice institutions fail to deliver rights, as is the case in India today, citizens may espouse new normative commitments while violating law-abiding behavior.

\section{EXTRALEGAL SETTLEMENTS AS A PRODUCT OF LEGAL CONSCIOUSNESS}

Legal consciousness, meaning how individuals perceive the law and respond to grievances, informs specific modes of legal mobilization. A relatively inclusive, multidimensional concept, legal consciousness connotes a broad set of thoughts, feelings, and behaviors related to the law (McCann and March 1996; Levine and Mellema 2001). It includes how people understand legal rights, how and when they make use of laws, how they assemble legal concepts, and how they interact with legal institutions (Ewick and Silbey 1998). More concisely, it is a commonsense understanding of how the law works as well as its norms and logics (Nielsen 2000; Engel and Engel 2010). 
Legal consciousness varies across demographic groups, to be sure. Class, gender, race, age, and educational status are important determinates (Blackstone, Uggen, and McLaughlin 2009; Morrill et al. 2010). But institutional and organizational contexts also shape people's interpretations of law (Albiston 2005; Hirsh and Lyons 2010; Chua 2012; Reynolds 2018). Individuals figure out how they will respond to difficult events through their experiences with concrete legal institutions and law enforcement personnel (Merry 1990; Sunshine and Tyler 2003; Young 2014).

Uneven legal-institutional environments engender multiple and sometimes conflicting orientations toward the law. Within these conditions, positive changes in feelings of individual efficacy and competency vis-à-vis the law can accompany negative evaluations of the legal system in terms of its fairness and effectiveness (Gallagher 2006). Such conflict is starkly visible in spaces where state law is weak and where alternate organizations command social and political power. People living in refugee camps, for example, find themselves alienated from local law while simultaneously feeling deeply embedded in the international legal system (Holzer 2013).

In this Article, I theorize how the political economy of what I characterize as a "stalled" legal environment gives birth to an "aspirational-strategic" legal consciousness among citizens, which in turn enables extralegal settlements. "Stalled" legal environments combine two contradictory features: political pressure for rights with systematic lack of enforcement. This combination is evident in the Indian case, which suffers from a fundamental disjuncture between the politics and application of law. On the one hand, a host of civil society organizations mobilize around legal reform and encourage individual women to make rights claims. Yet, criminal justice institutions rarely award benefits in favor of survivors and consistently fail to enforce verdicts.

"Stalled" environments are arguably not domestic violence specific, nor are they India-specific. This kind of environment may be found in spaces that combine a strong civil society presence with limited state capacity. Notably, over the past several decades, social movements and civil society groups have pressured local governments to expand human rights protections in a range of places. These various political campaigns have succeeded in vernacularizing rights discourse, diffusing human rights norms, and enacting legislative changes (Levitt and Merry 2009; Risse and Sikkink 2013). Yet, many criminal justice institutions remain ill-equipped to process and enforce new rights standards. These constraints are especially visible in contexts where state bureaucracies are underfunded and suffer from a range of coordination issues that make them incohesive and unembedded from the populations they govern (Kohli 2004; Evans 2012).

In the process of interacting with this environment, citizens may develop a bifurcated understanding of the law as something that simultaneously houses a vision of justice worthy of emulating, but whose operations are corrupt and needful of manipulation. They come to aspire to the life the law promises while distrusting the law's ability to ensure that kind of life. This dual consciousness arose within the survivors I tracked and interviewed. Navigating a landscape that promised rights but frustrated at every turn, survivors ended up believing they deserved what the law promised while simultaneously losing confidence in the legal process. As a result, they engaged the law, registering cases, but felt that it would be unwise to put too much faith in the law's ability to deliver justice. They were quick to use legal cases to threaten abusers, and when possible, to drop a case if their abusers granted certain concessions. 


\section{RESEARCH METHODS}

Criminal cases against domestic violence fall under Section 498A of the Indian Penal Code. ${ }^{2}$ Section 498A recognizes "physical and emotional cruelty" within marriage and carries a maximum sentence of three years and a monetary fine if violence is proven in court. ${ }^{3}$ Section $498 \mathrm{~A}$ is a non-compoundable, cognizable, non-bailable offense. In other words, cases cannot be legally withdrawn or settled out of court once they have been registered (noncompoundable). The police have the authority to arrest accused parties and conduct investigations without a warrant (cognizable). And accused parties cannot negotiate bail terms directly with the police without a court hearing (nonbailable).

Cases registered under Section 498A are processed by the police and district courts. Survivors initiate cases by registering a First Incident Report (FIR) with the police, who are then legally mandated to complete several tasks: locate and bring the accused into custody, conduct an official criminal investigation, draw up a charge sheet detailing the results of their investigation, and forward the charge sheet along with a copy of the FIR to the district magistrate's office for trial. The magistrate's office oversees bail proceedings and works with the public prosecutor and the police to locate witnesses and gather evidence for trial. Since India officially abolished its jury system in 1973, it is the magistrate who delivers an official verdict at the end of a trial.

How did 498A cases, formally defined by mandatory arrest and trial proceedings with strict limitations on bargaining and out-of-court settlements, lead to extralegal settlements? I answer this question using data I gathered through fieldwork in the state of West Bengal. West Bengal consistently registers one of the highest proportions of 498A cases in the country. By year-end 2016, the state had registered 19,302 First Incident Reports, accounting for 17.5 percent of all registered cases in the country (National Crime Records Bureau 2017). Yet, as in other parts of India, these cases were often illegally settled out of court through extralegal negotiation.

The data in this Article comes from two sources: in-depth interviews with thirty survivors who registered 498A cases, and participant observation of their interactions with civil society organizations and law enforcement personnel. I used a snowball sampling technique to recruit research participants (Weiss 1995). I first scheduled meetings with well-known women's rights activists in West Bengal. Through them, I gained introductions to women's organizations that provided legal aide to survivors in three different parts of the state: the capital city of Kolkata and two adjoining rural districts, North-24 and South-24 Parganas. These areas are marked on Figure 1 below.

I initially recruited research participants through women's organizations. The women I met within these venues in turn introduced me to other survivors in their

2. While Indian legislators have adopted a series of other provisions to counter domestic abuse over the past several decades, including the latest Protection of Women from Domestic Violence Act of 2005, I focus on 498A cases to understand extralegality. Section 498A's mandatory provisions prohibit negotiation and bargaining. As a result, the extralegal outcomes of $498 \mathrm{~A}$ cases demand inquiry and explanation.

3. Section 498A does not recognize sexual or financial violence, any kind of violence outside marriage, nor does it recognize violence within same-sex relationships. It restricts entitlements to legally married husbands and wives and does not offer civil remedies. Plaintiffs are guaranteed access to free legal representation through the office of the public prosecutor. 


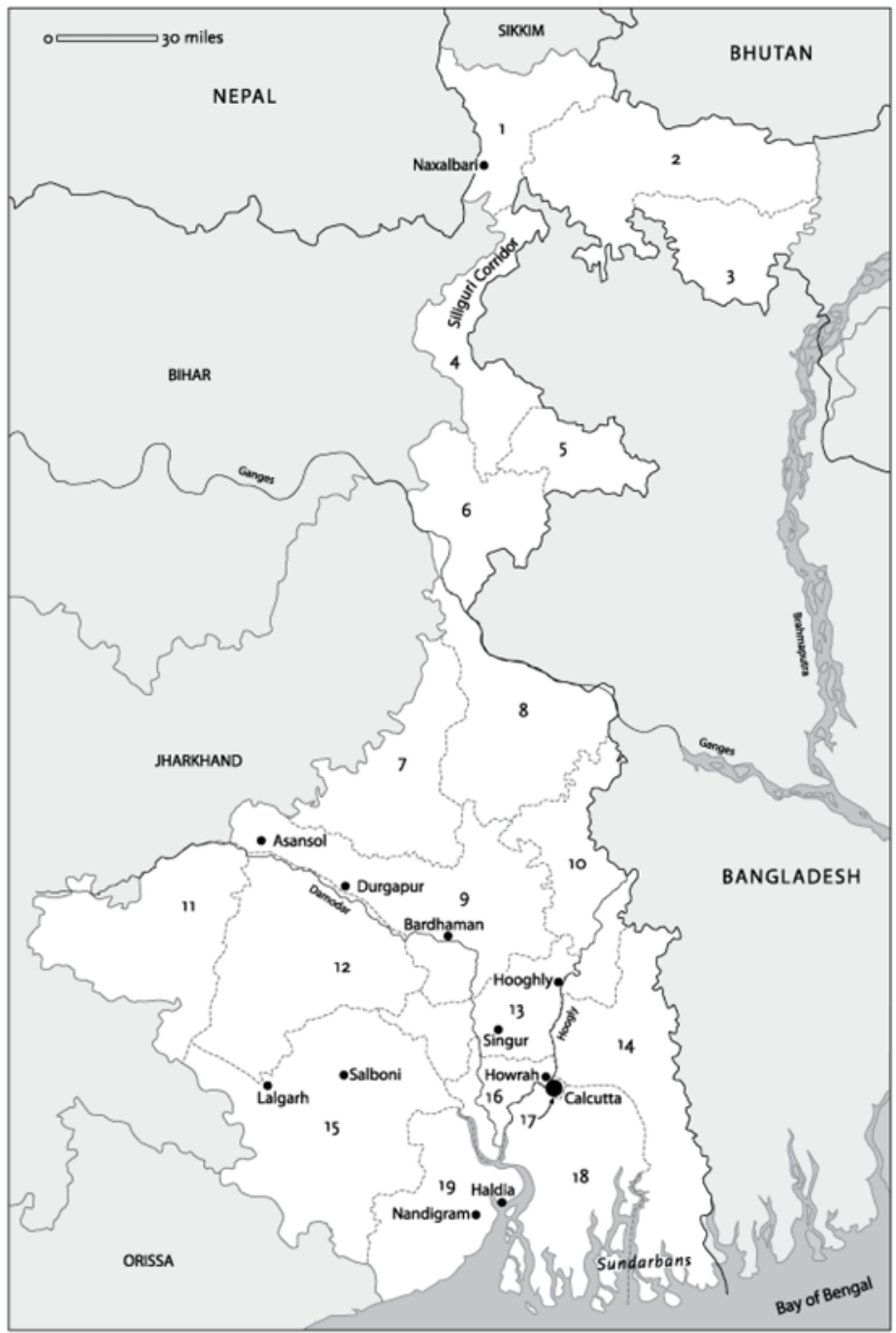

Key to districts:

$\begin{array}{llll}1 \text { Darjeeling } & 6 \text { Malda } & 11 \text { Purulia } & 16 \text { Howrah } \\ 2 \text { Jalpaiguri } & 7 \text { Birbhum } & 12 \text { Bankura } & 17 \text { Calcutta } \\ 3 \text { Cooch Behar } & 8 \text { Murshidabad } & 13 \text { Hooghly } & 18 \text { South 24 Parganas } \\ 4 \text { North Dinajpur } & 9 \text { Bardhaman } & 14 \text { North 24 Parganas } & 19 \text { East Midnapore } \\ 5 \text { South Dinajpur } & 10 \text { Nadia } & 15 \text { West Midnapore }\end{array}$

\section{FIGURE 1.}

\section{Map of West Bengal.}

personal networks. A sizeable number of the survivors (twenty) I talked to thus worked with women's rights groups. But all of them at one point or another interacted with a civil society organization that provided legal advice, including neighborhood associations and political parties, if not with direct legal aid services. While this feature of my sample may seem unusual, it is in fact emblematic of how women make claims against violence in India. Qualitative studies as well as large-scale surveys indicate that 
TABLE 1.

\section{Survivors by Social Background}

\begin{tabular}{llll}
\hline Location & Religion & Caste & Income \\
\hline $\begin{array}{c}\text { 20 South-24 Parganas and } \\
\text { North-24 Parganas district } \\
\text { (villages and small towns) }\end{array}$ & 12 Hindu & 4 Upper Caste & 3 Middle \\
& & & \\
& & 8 Lower Caste & 1 Low \\
& & & 7 Middle \\
& 4 Muslim & N/A & 1 Middle \\
& 4 Christian & N/A & 3 Low \\
& & N/A & 3 Middle \\
10 Kolkata (urban) & N Hindu & 3 Upper Caste & 1 Low \\
& & 5 Liddle \\
& & N/A & 0 Low \\
& & N/A & 1 Middle \\
& & & 4 Low \\
& & & 2 Middle \\
\end{tabular}

the vast majority of women approach the criminal justice system through civil society groups who train them and advocate on their behalf (Burton, Rajan, and Bhatla 2002; International Institute for Population Sciences 2016).

Survivors varied in their residential location (urban/rural), religious affiliation (Hindu, Muslim, or Christian), caste (upper or lower for Hindus; not applicable for Muslims and Christians), and income (middle or low). I purposefully recruited survivors from diverse walks of life, to see if social background shaped their relationship to law and legal institutions (Panda and Agarwal 2005; Duvvury, Nayak, and Allendorf 2002). Table 1, located below, provides a detailed breakdown of survivors' characteristics.

I assigned caste and religious categories according to research participants' selfidentifications. "Caste" refers to a system of social stratification among Hindus, rooted in occupational segregation and cultural notions of ritual purity and pollution. "Upper" and "lower" are legally recognized classifications within India. Classifying women's income level proved to be a tricky business partly because financial deprivation is often a feature of domestic violence. Taking this into account, I asked survivors to identify how much they personally consumed on a daily basis. If someone reported living on $\$ 1 /$ day or less (at the time the study was conducted, \$1 was roughly equivalent to 50Rs), I classified her as low income. If she was living on anything between $\$ 1-\$ 3$ (50-150Rs) per day, I classified her as middle-income.

I conducted all interviews in Bengali, my native language and the language of my informants. Interviews lasted anywhere from one to four hours, were loosely structured and conversational in nature. I avoided conducting interviews in survivors' homes if they were still living with their abuser in order to ensure their safety. I used interviews to understand how they thought of the law and what kinds of strategies they believed 
were effective forms of engagement. In other words, interview data helped me analyze if and how women's understandings of the law drove compromises.

Interview data supplemented data gathered through long-term participant observation of 498A cases. I followed survivors through the various stages of their legal claims, beginning with the registration of an FIR, to trial, to sentencing (in the rare case where a survivor received an official verdict). I observed survivors' interactions with NGO caseworkers during intake and advisory sessions, where people decided on next steps and case strategies. I did not gain access to confidential meetings between lawyers and survivors, but did witness their informal conversations in court around trials. While interview data helped me understand what women thought about the law, ethnographic data helped me document how they mobilized legal concepts and interacted with law enforcement personnel. Participant observation allowed me to separate discursive framings from strategic practices (Jerolmack and Khan 2013, 2014).

Proceeding through referrals greatly aided my abilities to conduct this research. I was able to establish trust with research participants, especially survivors who may otherwise have been reluctant to confide in a stranger. Partly because I met people through local references, partly because of the length of my tenure in West Bengal, and partly because I myself am an Indian-American woman who was born in Kolkata but raised in the United States, I gained what some sociologists have termed an insider/outsider status (Naples 1996). This position came with certain advantages as well as drawbacks. Access was its main advantage. I quickly integrated into the local work cultures of several women's organizations, was allowed to sit in on high-level managerial meetings, and included in sensitive intake sessions. I also became a recognized figure among survivors who saw me moving in and out of police stations and courtrooms, accompanying caseworkers and other survivors. Meanwhile, my ability to ethically and analytically separate myself from research participants turned out to be the main drawback of being an insider/outsider. People often mistook me for a caseworker or a lawyer or a women's rights activist, expecting that I would provide advice and legal help. I had to work hard to correct them.

\section{STALLED: THE LEGAL ENVIRONMENT SURROUNDING DOMESTIC VIOLENCE}

The legal institutional environment in my research site combined two contradictory features: political mobilization and organized support for rights claims with systematic lack of enforcement on the part of criminal justice institutions. A growing number of nongovernmental organizations and civil society groups encouraged women to make use of domestic violence law-recasting their experiences as instances of abuse and helping them register legal cases. On the other hand, the criminal justice institutions that were in charge of implementing domestic violence law systematically failed to deliver rights.

Since India gained independence from colonial rule, Indian legislators have adopted three major reforms against domestic violence, of which Section 498A has been a major component. First, in 1961, parliament passed the Dowry Prohibition Act 
to control dowry-related harassment and murder within Hindu families. ${ }^{4}$ In 1983, Section 498A of the Indian Penal Code criminalized abuse beyond dowry-related violations. ${ }^{5}$ A final round of reforms in 2005 led to the passage of the Protection of Women from Domestic Violence Act (PWDVA), which covered women in a range of domestic relationships and provided a variety of civil remedies, including protection orders, alimony, and residential rights (Uma and Grover 2010; Ghosh and Choudhuri 2011).

Members of the Indian women's movement pushed legislators to undertake the legal reforms that are on the books today (Purkayastha et al. 2003; Kannabiran and Menon 2007). Women's rights activists, women's NGOs, and feminist lawyers staged direct action campaigns across the country, conducted petition drives, and worked with friendly legislators to redraft both criminal and civil law. Women's organizing has accompanied a growth in institutional sources of legal aide. Nongovernmental organizations, women's committees (locally known as mahila samiti), neighborhood councils, unions, and even political parties provide legal counsel, advice, and run awareness workshops targeting local communities (Burton, Rajan, and Bhatla 2002).

NGOs and women's committees promote notions of women's empowerment, thinking of their legal aid activities as vehicles for changing gender relations in progressive directions (Roychowdhury 2016a). These organizations also provide strategic advice to women, instructing them on the ins and outs of law enforcement personnel. And many expressly provide "muscle power," granting strength through numbers that allow individual women to threaten abusers and law enforcement personnel alike (Biswas 2007). As a result of these grassroots mobilizations and this institution building, survivors now tend to approach multiple institutions for help and advice before or directly after approaching law enforcement personnel (Rao et al. 2000; Roychowdhury 2015). And many women have a growing awareness of their rights as well as a sense that legal cases might improve their situation.

While these organizational forces train survivors to desire rights and manipulate the law, the Indian criminal justice system continues to perform abysmally (Agnes 2005; Ray 2006). If we go back to 2006, we see that approximately 21.9 percent of cases tried under Section 498A led to an official conviction. Pendency rates were high, with 27.0 percent of registered reports pending investigation within police stations and 84.8 percent of cases pending trial in court (National Crime Records Bureau 2007). Since 2006, legal outcomes have steadily worsened. By year-end 2016, Section 498A had the lowest conviction rate of all crimes prosecuted under the Indian Penal Code, with 12.2 percent of tried cases leading to conviction (National Crime

4. Dowry refers to the customary practice of Hindu brides bringing cash, jewelry, and other financial assets from their natal families to their husband's home. Dowry harassment refers to a situation where husbands and in-laws abuse women who are unable to meet dowry demands, resulting sometimes in dowry-related murder where a man kills his wife in order to marry again and receive another dowry.

5 Prior to the passage of IPC Section 498A in 1983, married women could seek limited remedies against domestic violence under religiously based personal laws and through general provisions under criminal law against hurt, grievous hurt, wrongful confinement, and attempt to murder. For a discussion of the limitations of personal laws, refer to Jaising 2005. For a discussion of the inadequacies of general provisions, refer to Agnes 1992. 
Records Bureau 2017). ${ }^{6}$ Meanwhile 32 percent of registered reports remained pending within police stations and 90.6 percent of cases remained pending in court. The central government does not compile data on how long each case remains pending. But regionalized studies indicate that the average 498A case remains open for over ten years (Centre for Social Research 2005).

The Indian criminal justice system's poor performance with domestic violence is part of a more general predicament. Courts and police stations, the two institutions that play the biggest role in criminal cases, are severely overburdened. By 2016, India's High Courts had a vacancy rate of 42.4 percent, functioning with 601 out of an approved 1,044 judges (Prakash 2016; PTI 2016a). Meanwhile, district courts were missing 4,432 judges. Overall, this meant that India had 17.8 judges for every million civilians (PTI 2016b). To place this number in context, the United States had 107 judges for the same number of civilians.

The police fare even worse than the judiciary. India has one of the lowest police to civilian ratios in the world and police strength has declined over the past five years. While the United Nations recommends a ratio of one officer for every 222 civilians, by 2015, India had one police officer for 720 civilians (BPRD 2015). Notably, a mere 11 percent of the national police force included Assistant SubInspectors, Sub-Inspectors, and Inspectors, the ranks that oversee criminal investigations (Saravade 2015).

These unfavorable conditions in police stations and courts mean that criminal cases against domestic violence tend to get bogged down in never-ending trials: justice is rare and never swift. It also means, however, that law enforcement personnel command a weak monopoly over violence and suffer from job insecurity (Human Rights Watch 2009; BPRD 2015) As a result, they can be threatened, bribed, and politically influenced by organized citizens and violent demonstrators (Brass 2005; Hansen 2009; Roychowdhury 2016b).

The incapacity of the criminal justice system means that for ordinary citizens, rights are almost never guaranteed. But the vulnerability of that same system to political influence and pressure, meanwhile, creates openings for those who can get together, get organized, wheel and deal, and level threats. Together, these conflicting tendencies provided a ripe foundation for women's aspirational-strategic consciousness, and their willingness to settle out of court.

\section{ASPIRATIONAL COMMITMENTS: BELIEVING IN A LIFE FREE OF VIOLENCE}

For survivors, the very act of registering a 498A case reflected a powerful kind of aspiration. Before one can make a legal claim, one must first perceive one's experiences as injurious-naming the experience as a violation, and then formulate a grievance, blaming someone for the injurious act (Felstiner, Abel, and Sarat 1980). Most survivors of domestic violence in India never reach these initial steps. In fact, 52 percent of

6. IPC crimes have an average conviction rate of 45.1 percent. Interestingly, conviction rates for domestic violence tend to be significantly lower even than that for rape (28 percent in 2016). 
women surveyed by the Demographic and Health Survey said that husbands are "justified" in beating their wives under certain circumstances (International Institute for Population Sciences 2017). ${ }^{7}$

To some extent, the women who participated in my research fell outside of the aforementioned category. They had come forward. They acknowledged they had experienced harm. And they sought some kind of solution. But the solution they originally sought almost never involved the law. The survivors I talked to sought help from local organizations because they wanted to work things out and remain with their abusers. Most had asked civil society actors to "scold" (boke deo $\bar{a})$ their abusers so they would behave themselves. They hoped to reconcile and "run a family" (sansār cālāno): manage a household and provide care for husbands, children, and extended families in line with dominant social expectations.

Others wanted help separating from their abusers and asked NGOs for information on job training programs. But even these women feared that a criminal case did not represent their interests or their desires for the future. They believed the popular discourse that women who registered 498A cases were malicious and "abusive." They had little desire to become one of those women. And in these initial orientations away from the law, the survivors I talked to mirrored the vast majority of Indian women who have experienced intimate abuse. Survivors routinely reject criminal cases because their adversarial nature breaks apart relationships and families (Das 1996; Sen 2010; Suneetha and Nagaraj 2010).

Against this backdrop, registering a 498A case takes a special kind of ambition. By registering a case, a survivor announced to her family, her abuser, and to herself, that she was willing to take a dramatic step to end the abuse she suffered. In exchange for the possibility of a life without violence, she would allow the police and courts, lawyers and activists, to root around in her private affairs and possibly drag her good name through the mud. Jhumpa, a working class, lower-caste Hindu woman in her early forties who lived in south Kolkata, epitomized this reorientation.

Small, dark, with bright eyes and a mass of wavy, shoulder length hair, Jhumpa married for love at the age of sixteen. The marriage went well at first, but soured over the course of multiple miscarriages. Jhumpa's husband blamed her infertility on what he perceived to be her moral degeneracy—verbally and physically abusing her as punishment for her suspected sins. He eventually abandoned her, taking a job in a different part of the city where he began living with another woman. By the time I met Jhumpa at a women's NGO in Kolkata, she had already been fighting a 498A case for five years.

Jhumpa recalled how much she had changed since her husband's departure. "If you saw me then, you would never think that girl would fight a case," she laughed. Like other survivors I talked to, she too had hoped to "run a family." She had approached the women's NGO where we met with that expressed goal. "I kept wanting [the NGO caseworkers] to return my husband to me, to get him away from his girlfriend and teach him to be nice." It had taken a great deal of courage and zeal

7. Men were less likely than women to say violence against wives is ever justified. Among surveyed men, 42 percent agreed that a husband can justifiably beat his wife under certain circumstances. For more see the National Family Household Survey 2015-2016 India Report, p. 512. 
to overcome her emotional attachments, which were not just for her husband but for an entire way of life.

By pursuing a criminal case, Jhumpa committed herself to the possibility of living alone. She claimed that freedom from harm could, under certain circumstances, be more important than marital obligations. Behind these reorientations stood the institutional education and support provided by the women's NGO she regularly visited. She was certain that she would never have registered a legal case without her caseworker's help. By taking her situation seriously and informing her about her legal options, Jhumpa's caseworker had made her aware that there was even a law to which she could appeal. "I had never heard of 498A," Jhumpa recalled. By supervising the early steps of her 498A claim, it was also her caseworker who made the promise of legal rights seem somewhat attainable. Meanwhile, it was through the NGO's gender awareness programs that Jhumpa linked her own personal problems to a general predicament that other women faced. She learned that "girls also have rights" (mēēe der o adhikāra $\bar{a} \operatorname{ch} \bar{e})$.

Like Jhumpa, other survivors learned to aspire through the civil society organizations they contacted for help, organizations that not only raised awareness of gender inequality but also provided positive examples of women who had pursued legal cases. Sabiha, a working-class Muslim woman from North-24 Parganas who earned money as an agricultural worker, was acutely aware that by registering a 498A case she was committing herself to an image of femininity she had previously denigrated. She registered her own case after completing a legal awareness workshop sponsored by the women's wing of her peasant's union. Through her involvement with the union, which negotiated both domestic violence cases and collective bargaining agreements with local landlords, Sabiha had gotten to know other women who had separated from their husbands. These women provided alternative normative models, encouraging Sabiha to change her views on the ethics of legal cases.

Mentioning these women's names, she reasoned that giving up her husband was a sacrifice she was willing to make to privilege other values she now held dear, including setting a good example for her daughter. She admitted that in the past she had looked down on women who had left their husbands, judging them to be selfish. But getting to know women who had pursued cases and were generous and kind made her reassess the moral value of a legal claim. Sabiha blamed her conservative upbringing and illiteracy on her earlier lack of awareness. She had never been taught the "value" (mülya) of an independent life. As a girl, she had been trained to be "subservient" (parādhīn) to the men in her family, and especially to her husband. She argued that these days, she felt a keen desire to change her circumstances, no longer fearing the "freedom" (sâdhinat $\bar{a})$ that legal cases promised.

The assumption that only disreputable women bring 498A cases remains ubiquitous in West Bengal. One finds it by opening any mainstream newspaper, turning on the television, and conducting a simple Google search for 498A, where the top hits broadcast the dubious notion that women make up false allegations. The notion that "bad" women use 498A has also found its way into a wide range of activist circles (Kishwar 2003), motivated parliamentary drives for legal amendment (Koshyari 2011), and initiated Supreme Court directives encouraging police stations to suppress charges (Mahapatra 2014). Faced with this prevalent connection between women's immorality 
and the mere act of claiming legal rights, it is far from surprising that Jhumpa and Sabiha initially felt the way that they did.

Ashu, a middle-class, Christian woman who lived in a large town in North-24 Parganas, succinctly captured the importance of this transformation. When I first met her, she expressed a strong disdain for legal cases and had not yet sought any kind of assistance. Legal cases were "unrespectable" (abhadra) ventures for middle-class women, she reasoned. By the end of my research, she questioned her earlier stance. A friend of her father who was a retired lawyer and now ran the neighborhood association where she lived had encouraged her to register an FIR against her ex-husband. "What is respectability (sam'māna) without a respectable life (sam'mānita jībana)?" She no longer cared to earn the respect of people who did not care about her safety or well-being.

\section{STRATEGIC VISIONS: MANIPULATING LEGAL RULES AND PROCEDURES}

Survivors who came to believe they deserved the life the law promised simultaneously learned to relate to the law as a tactical field that they could and should manipulate. Nestled within this vision was a strong distrust of law enforcement personnel and the suspicion that criminal justice institutions rewarded craftiness, rather than ruleabiding behavior. Instead of encouraging them to avoid the law, this distrust informed a practical kind of engagement, where survivors reimagined themselves as efficacious negotiators. In their minds, manipulation of the law did not contradict a commitment to legal rights, but rather helped ensure them.

The strategic component of a survivor's legal consciousness overlapped with commonplace understandings of law enforcement personnel corruption and malfeasance (Kapur and Vaishnav 2014; Vaishnav 2017). Ordinary citizens have long vilified the police, refusing to believe that they impartially enforce justice (Brass 1997). And people from marginalized communities are especially likely to say that courts provide inhospitable environments for grievances (Moore 1993). My respondents articulated a specific set of gendered anxieties about what it meant for them to ask male-dominated institutions for help against male violence.

Hema, who was working-class and lower-caste, laughed at the idea that the police would protect her. "Faced with my husband or the police, I would run toward my husband every time," she said. "The police are worse than the thugs they lock up." Hema feared that the police either ignored, or further violated women who were alone and weak. Given India's high rates of custodial rape and torture, her anxieties were not exactly unfounded (Commonwealth Human Rights Initiative 2010). In addition to voicing fears about law enforcement personnel, survivors mentioned law enforcement partiality toward the wealthy and powerful. "They don't respect us," Najma, a Muslim woman from a poor family told me in the midst of a rights awareness workshop in South-24 Parganas.

While distrust drove survivors to think strategically, their consciousness also arose from a certain level of knowledge about the law and law enforcement personnel as well as the self-confidence that came with familiarity. On average, working-class and 
middle-class Indian women know very little about the state, laws, or the legal process (Corbridge et al. 2005). Because private and public spheres are heavily gendered, politics and civic associational life remain male-dominated realms, excluding women from the usual channels that citizens use to learn about the state. Thus, thinking strategically about the law is not all that commonplace for ordinary women. It was through exposure to civil society organizations as well as the criminal justice system that the survivors I met came to see the law as something they could participate in and influence.

Here, Jhumpa's recollections are again instructive. Thinking back to the time when she first decided to register a 498A case, Jhumpa remembered feeling acute fear of law enforcement personnel, wanting to avoid them at all costs. "The first day I went to court, I was trembling." But by talking to court personnel, entering a police station, all of these people and spaces that had been unfamiliar and intimidating became familiar and negotiable. "It's different now. Once you get accustomed to a place, it's not so intimidating. Some people are helpful, others aren't. You have to force them to get to work... I still don't trust the police, but I've realized they are more lazy than anything else."

Jhumpa, who had trembled in fear when she first went to court, came to believe that women like herself could "force" law enforcement personnel to do their jobs. She spoke to me about the tools she could use: bribery, mobilizing connections through political parties, using civil society organizations to apply pressure through the upper reaches of the criminal justice bureaucracy. It was this idea-that as a relatively powerless woman, she could still partake in the legal process and attempt to bend it to her will — that informed Jhumpa's strategic orientation toward the law. While she was suspicious of the law and its personnel, she also believed it to be a site that could be worked upon and worked to her advantage.

Survivors' interactions with the criminal justice system rendered these institutions and institutional personnel less monolithic. Hema, who joked that she would rather run toward her husband than the police, later qualified her statements. "Not all of them are bad," she noted of the police. "Some of them see things from a girl's perspective." Identifying who would take a girl's perspective, or who could be "forced" to do their job and through what kinds of tactics became part of survivors' strategic quest. For Hema, figuring this out required the assistance of a women's organization in her district. She recalled how the constable at her local station had refused to register her case. But "the didis [caseworkers] know who to call." One of them knew the officer in charge of the police station. "He made sure my case got registered."

Yet, no matter how much one "forced" law enforcement personnel to deliver, survivors recognized there were limits to their abilities to access formal remedies. "The cases I have heard about, they get to a certain point and then they get stuck," Ashu remarked. By recognizing the law's limits, survivors strategized not only about how to move their cases forward within the criminal justice system, but also how to use a case to extract concessions outside legal institutions. "You have to play mean with bad people," Ashu argued. Having given up hopes of attaining "respectability," Ashu reasoned that there was a kind of power involved in using what she had at her disposal. Her strategic consciousness of the law drove her to see its informal possibilities. 


\section{SETTLED: FORGOING OFFICIAL RESULTS FOR EXTRALEGAL RESOURCES}

Simultaneously believing they deserved rights while recognizing that the criminal justice system was unlikely to award them, survivors registered legal cases but remained open to the possibility of using the case as a bargaining chip. Like Ashu, who believed one had to "play mean," survivors learned to use a number of illicit tactics to push their cases forward, toward whatever end-official or unofficialwas feasible. They gathered their own evidence, illegally filled out and ferried government forms, cajoled and threatened witnesses to ensure they showed up to court, bribed the court clerk to secure a speedy trial date. They also worked to enlarge and strengthen their social networks within women's organizations and political parties, so that when needed, they could use organized groups to threaten abusers and law enforcement personnel.

Of the thirty survivors I tracked, only four secured an official judgment on their 498A case either before or by the end of my research project. While 498A cases rarely resulted in state-based rights, they did have significant extralegal consequences. In my study, 498A cases resulted in five kinds of settlements: financial settlements, repossession of personal property, child custody, formal separation, and residential rights. Survivors frequently accessed two or more of these outcomes at once. Notably, none of these outcomes are guaranteed by Section 498A. ${ }^{8}$

When discussing these extralegal outcomes, survivors used a particular vocabulary. They did not refer to gains outside the law as bicār, which connoted a juridical form of justice. Rather, they used words such as "atonement" (prāyśchitha) and "justice for wrongdoing" (an'yāyēer pratiśōdh), terms that better captured extralegal, moral claims to justice. The word mīmānsā ("compromise," "settlement," and "solution" in Bengali) provided a catchall the described the process whereby survivor attained illicit justice.

A financial settlement took one of two forms: a monthly allotment, or a lump sum transfer of cash or other assets from the abuser to the survivor. Because monthly installments offered abusers multiple opportunities to default, survivors preferred one-time lump sum transfers. While child custody settlements are relatively self-explanatory, repossession of personal property involved situations where survivors regained access to a host of personal items that their husbands initially refused to give back. Among the items survivors sought, gold jewelry gifted by their parents upon marriage, a local custom for women of all religious backgrounds in West Bengal, always featured at the top of the list. In addition to gold, survivors also hoped to regain items such as clothing, furniture,

8. The illicit settlements survivors negotiated through $498 \mathrm{~A}$ mirrored the remedies provided by PWDVA, the latest civil act against domestic violence. Survivors were in effect, using the older criminal law to access what the 2005 civil act might have formally given them. This circuitous route raises the question of why they were registering 498A cases when they could have registered PWDVA cases? I found two main reasons. First, civil cases were too expensive for working-class and poor women. Second, and in line with my general findings about the strategic uses of law in India's "stalled" environment, survivors believed that the threat of arrest that came with Section 498A gave them an extra weapon in the negotiation process, one that was unavailable under civil law. 
and kitchen utensils and appliances they had received as gifts before marriage. Others were able to secure much needed housing and much desired separations. ${ }^{9}$

These settlements were overseen by civil society organizations and sometimes also by law enforcement personnel, who provided a kind of "formal" institutional presence enforcing informality. It was through their NGO caseworkers, political party representatives, and neighborhood women's committees, those who were experienced in the law, that survivors learned the strategies they could use to get ahead. And while civil society organizations taught survivors how to manipulate legal rules and procedures, the criminal justice system tolerated and rewarded such behavior. As Hema noted, law enforcement personnel could be persuaded, through money or personal favors, to take a girl's side. Or, as in Jhumpa's words, they could be "forced" through organized pressure or the threat of physical violence.

Jhumpa's settlement with her husband, for instance, was overseen by a Kolkatabased NGO and unofficially enforced by a police officer on friendly terms with the NGO's staff. In addition, Jhumpa elicited the social support of men who worked for the political party that controlled her neighborhood. The settlement process began when Jhumpa's husband got fed up with receiving court summonses. He informed Jhumpa that if she stopped showing up to court, he would grant her a divorce and give up his claim on their apartment.

The women's rights NGO Jhumpa visited on a weekly basis agreed to sit down with her husband and make sure he actually signed the apartment title over to her name. The $\mathrm{NGO}$ then called their contacts at the local police station, eliciting the cooperation of a Sub-Inspector who agreed to make sure Jhumpa's locks were changed and her husband moved his possessions out of the house. Finally, Jhumpa talked to the "boys at the local club" - men who spent a good deal of time lounging around the headquarters of the political party that dominated her area. Having informed them of the agreement with her husband and gained their support, Jhumpa felt relatively assured that the apartment was in fact now hers. "He wanted the divorce anyway, so he could marry (again). But it doesn't matter. He's out of my life and I get to stay in our house." The promise of free housing and a life without violence trumped Jhumpa's desire to see her husband land in jail.

While survivors of all social backgrounds ended up settling, social background influenced how long survivors held on to an official case before negotiating. Poor survivors settled quickly, while women with greater financial resources waited longer to negotiate extralegal terms. For working-class women, formal remedies exacted a heavy toll because of the length of criminal cases. As a result, they were relatively more eager to pursue extralegal resolutions.

Some working-class survivors explicitly used case registration as a bargaining agent for out-of-court negotiations. Najma, the Muslim survivor from South-24 Parganas who lamented that the police did not respect poor women, registered a 498A case because it would help her negotiate a private deal. Najma discussed women she knew who had

9. Renting housing in India as a single woman is extremely difficult, and nowhere more so than in West Bengal where property laws are weak and landlords unwilling to rent to demographic groups they view as financially risky or "troubled." Single women are deemed to be both. These gendered hurdles in rental markets made the possibility of secure housing an important resource for survivors. 
registered 498A cases. She acknowledged that they had not received an official verdict. But according to her, an official verdict was never something these women had sought. Nor for that matter did she. "Their husbands gave them back their clothes and jewelry." In Najma's view, this was the outcome they had intended from the very beginning, and it was the ideal outcome.

Civil society groups who catered to working-class women's concerns knew how to broker compromises with great speed. Sabiha's husband initially refused to financially provide for her and their daughter, claiming that she had "abandoned" the marriage even though it was he who had beaten her and then moved in with his mistress. Bani, a lead caseworker and organizer at Sabiha's peasant's union, advised her to first see if he would budge by sending the union's members to harass him. When Sabiha's husband moved to his girlfriend's village to avoid the union, Bani gave the go ahead. "Hit him with a case" (case lāgāo). Bani and Sabiha believed that a criminal case would "burn" him out of hiding (jäliye chārbēe), driving him to the negotiating table.

Over time, the case did in fact have the desired effect. Weary of dodging an arrest order, Sabiha's husband agreed to give her a sum of $\$ 15,000$ RS (roughly $\$ 250$ at the time) if she agreed to a divorce and withdrew the case. The disbursement process took another few months to be completed and was policed by the union. Reflecting on the compromise, Sabiha concluded that the monetary settlement provided the best outcome for her. She had no desire to send her husband to jail, where he would lose his job and thus the ability to financially provide for her. Nor did she have the time or money to fight a trial. When she was not out in the fields, she cleaned people's homes for a living. Taking time off from these jobs meant losing valuable wages. And the bus fare back and forth from the district court house was itself a financial burden.

While working-class survivors like Sabiha and Najma entered 498A cases with the express purpose of attaining an out-of-court settlement, those who could afford to keep a case going held on as long as possible. The ability to wait allowed them to negotiate better terms for their agreements. Survivors who had a range of social and financial connections thus had a leg up in the illicit negotiating process over those survivors who could only count on civil society intervention.

Sharmila's trajectory from legal suit to settlement provides a case in point. A much-loved only child born and brought up in a middle-class, upper-caste Hindu family in south Kolkata, Sharmila was shocked by the treatment her husband and his family had meted out after her marriage. Her own parents thankfully remained supportive throughout the entire process, telling her to return home, paying for a private lawyer, and encouraging her involvement in a Kolkata-based women's NGO that ran support groups for survivors and provided free legal assistance.

With the help of her NGO caseworker Sharmila registered a 498A case. The NGO's in-house lawyer then advised her to get in touch with her local dada (literally meaning "elder brother" but referring to a politically connected fixer), a man who served as a broker between neighborhood residents and the ruling political party. Her dada's political connections came in handy when Sharmila had to approach the police. He would either accompany her to the station or call ahead before her arrival, easing the registration and investigation process. Sharmila also admitted to using her dada to send "sweets" (misti) to the Inspector in Charge of the police station, a euphemistic way of talking about bribes. 
Her connection with the dada, while initially good at moving the case ahead, eventually ran into its limits once the case entered the court. Her dada and his party affiliates had contacts among the court clerks and even with the District Magistrate, but the court was a juggernaut that ran at its own pace. When I met Sharmila, it had been four years since she registered her case. Having once been bent on sending her husband to jail, she now felt less motivated by that goal. Her husband had willingly granted her a divorce and returned large chunks of her dowry once he became aware of her political connections. With a shrug of her shoulders, she announced that she was relieved to have her jewelry back. She was also glad that the case had "made [her husband] suffer for a bit."

By using a range of illicit means, from political pressure to bribery, to move her official case forward Sharmila ended up convincing her husband that she was not to be ignored. Once he scrambled to appease her, she herself felt less motivated to keep fighting a legal battle. A situation akin to this transpired for Riya, an upper-caste Hindu woman born and brought up in North Kolkata. The only daughter of an upper middleclass family, she had received a hefty dowry that included gold jewelry passed down through several generations of women. For a year after their separation, her husband kept making excuses about returning her dowry, claiming that he still hoped for reconciliation. ${ }^{10}$ After Riya registered a 498A case, all conversation stopped between them and Riya fretted after her family heirlooms, worried her husband had sold everything for profit.

It was at this point that Riya decided to use personal connections to dig up evidence against him. Like many property dealers in Kolkata, Riya's husband had extensive black-market holdings: houses he had bought with "black" money. By illegally unearthing his property deeds through a friend at the bank, Riya hoped to give her lawyer evidence of her husband's poor character to use in court. Yet, in the end, her husband was far more afraid of losing his property than hoarding her gold. Upon hearing that she had these documents in her possession, he suggested a settlement: if she dropped the 498A case, he would return not just her jewelry but also the furniture her parents had given her and a chunk of the money she had been gifted upon their marriage. Satisfied with this bargain, and tired of fighting a case, Riya admitted that her goals had changed. "I have what I went in with. He doesn't get to keep anything of me," she explained with a sense of satisfaction.

\section{CONCLUSION}

The stories on these pages show how people simultaneously embrace legality and illegality. In my field site, survivors of violence registered formal cases that they then settled out of court. I have highlighted how this strategy was driven by the workings of an "aspirational-strategic" legal consciousness. On the one hand, survivors aspired to the kinds of lives legal rights promised. They believed they were entitled to live lives free of abuse and they deserved compensation for the pain they had suffered.

10. Dowry taking and giving was technically made illegal in India under the Dowry Prohibition Act of 1961. Despite its illegality, it remains a prevalent custom. It is also linked to various forms of violence against women, including dowry-related murder and harassment. For more, refer to Banerjee 2014. 
Concurrently, they embraced a strategic stance toward legal institutions. They argued that following legal procedure was a foolhardy policy, and that the safest thing to do was to adopt illicit means to attain justice. This dual consciousness arose in women of diverse class, caste, and religious backgrounds. It was a product of the institutional landscape they traversed, a landscape defined by unfulfilled legal mandates and governed by civil society organizations and criminal justice institutions that encouraged cunning legal engagements.

These findings indicate that expansions in legal rights may have contradictory effects on rule of law when legislative reforms accompany uneven institutions. Rule of law is defined broadly as a society's adherence to a body of law representing a social consensus on the rules of justice (Gibson 2004). Shared social norms, people's belief that the law is just, is key to the rule of law, as is procedural adherence, their willingness to abide by its rules (Fukuyama 2010). States play an important role in ensuring the conditions for such adherence, including equality of all actors under the law and predictability in the application of law (Chavez 2003).

The Indian criminal justice system's failure to enforce domestic violence law further encourages survivors to ignore legal rules and procedures and settle out of court. But it is important to realize that these negotiations do not merely happen to women. Rather, survivors actively take part in and initiate these transactions. Survivors referred to the end product of their legal ventures as "settlements" rather than "compromises," indicating that to some extent, they received what they wanted out of the legal process.

And at the same time, as they manipulated the legal process, survivors' actions also indexed a strengthening of the rule of law. The very fact that women are registering legal cases and that civil society groups find domestic violence cases to be an organizationally useful area to get involved in, showcases the power of law. By defining certain acts as socially and morally reprehensible, rights can thus create new norms and propel people toward the law and its institutions. New groups of people, including women themselves, believe in and are compelled by visions of gender equality in my field site. India's compromised cases indicate that progressive changes in norms may not necessarily entail obedience to legal rules or institutions.

My findings provide lessons beyond domestic violence and beyond India. The fact remains that the kind of "stalled" environment that characterizes the legal climate in my field site is far from India specific. Recent expansions in legal rights have created an uneven institutional landscape in a number of parts of the world, especially in developing, post-colonial countries (Berliner et al. 2015). These are the spaces where weak states coexist with transnational initiatives aimed at promoting legal rights (Caple James 2010; Lake 2014) as well as local bodies that exercise sovereign functions (Hansen and Stepputat 2005). Those who attempt to access rights under such conditions may come to behave similarly to the women who feature on these pages.

Survivors' "aspirational-strategic" consciousness may thus be useful for understanding a variety of citizen behaviors outside my field site. In Latin America, for example, citizens approach the law for assistance but relate to legal institutions through a variety of illicit tactics largely because state officials enforce laws in partial ways and biased ways, yet ordinary people are embedded in powerful civil society movements for rights (Mendez, O'Donnell, and Pinheiro 1999; O'Donnell and Schmitter 2013). The law, in these contexts, simultaneously provides a means of manipulation and legitimacy by 
which diverse actors advance collective and individual interests (Holston 2008). Similarly, in South Africa, the boundary between legality and illegality collapses for the urban poor, who are encouraged to take responsibility for their own crime prevention by an absent state (Super 2016). These are the kinds of contexts where "aspirational-strategic" consciousness may abound. Here, we see citizens simultaneously approaching and engaging legal institutions, while flouting legal rules and using official cases to advance a variety of unofficial goals.

Does this mean that rights are sometimes "wrong"? Variations of this argument are visible in Talal Asad's critique of rights, whose Christian origins he finds to be at odds with non-Western contexts (Asad 2000). It is also central to Gayatri Spivak's argument that "responsibilities" are a more salient category than rights in the South Asian context (Spivak 2004). On the specific case of gender-based violence, Ratna Kapur claims that legal statutes against sexual violence frame notions of consent and violation in starkly different terms than popular discourses in India (Kapur 2005). While the women I met brought localized definitions of harm, consent, and compensation to their legal ventures, what I have concerned myself with on these pages is the way the political economy of legal institutions informed survivors' beliefs and actions. Strikingly, survivors did not have static visions of harm. They quickly adapted their views in relation to the institutional messages that surrounded them.

On view before my eyes was the emergence of a messy, entangled consciousness, where people's conceptions of law and justice emerged from ongoing contact with nonstate institutions as well as juridical visions of justice, however absent and unattainable (Kaviraj 2005; Randeria 2006). Their aspirational-strategic subjectivities combined the language of law and legal rights with distrust and tactical acceptance of illegality. My research provided striking proof of what some have identified as a popular understanding of the Indian state as simultaneously sublime and profane, a site that embodies an ideal of justice but which has become corrupted and thus needful of extralegal action (Khilnani 1999; Hansen 2001; Kaviraj 2005).

Rights are not necessarily "wrong" in India, or anywhere else in the world for that matter. Rights discourse is by definition "light": indeterminate, malleable, and variable (McCann 2014). But as symbols, rights can gain positive weight through collective action (McCann 2006). When the core content of legal rights remain unenforced, rights discourse can nonetheless have beneficial side effects (Massoud 2011) These unintentional outcomes are apparent even in authoritarian contexts such as Sudan, where human rights standards provide pathways to immediate forms of relief such as food and education (Massoud 2013).

For the survivors I met, the unintentional consequences of rights cannot be easily dismissed. They spelled the difference between financial survival and penury, between having housing and not having it. And the stories underlying extralegal settlements indicate that legal reforms have helped expand normative commitments to women's rights, both among civil society actors and among survivors themselves. Without laws on the books, it is unclear if survivors would have been able to negotiate at all. Section 498A provided a space within which extralegal negotiations could happen. By engaging the law, survivors of violence imagined an expanded realm of possibilities for their lives and sometimes succeeded in attaining otherwise unattainable material and social resources. 


\section{REFERENCES}

Agnes, Flavia. "Protecting Women against Violence? Review of a Decade of Legislation, 1980-89." Economic and Political Weekly 27, no. 17 (1992).

—. "The Violence Against Women Campaign: Where Have We Failed?" Available at www. infochangeindia.org (2005).

Albiston, Catherine "Bargaining in the Shadow of Social Institutions: Competing Discourses and Social Change in Workplace Mobilization of Civil Rights." Law $\mathcal{E}$ Society Review 39, no. 1 (2005): 11-50.

Asad, Talal. "What Do Human Rights Do?" Theory Ë Event 4, no. 4 (2000).

Banerjee, P. R. "Dowry in 21 $1^{\text {st }}$-Century India: The Sociocultural Face of Exploitation." Trauma, Violence $\mathcal{E}$ Abuse 15, no. 1 (2014): 34-40. doi: 10.1177/1524838013496334.

Basu, Srimati. "Judges of Normality: Mediating Marriage in the Family Courts of Kolkata, India." Signs 37, no. 2 (2012): 469-92. doi: 10.1086/661712.

- The Trouble with Marriage: Feminists Confront Law and Violence in India. Berkeley, CA: University of California Press, 2015.

Baxi, Pratiksha. "Justice Is a Secret: Compromise in Rape Trials." Contributions to Indian Sociology 44, no. 3 (2010): 207-33. doi: 10.1177/006996671004400301.

Berliner, Daniel, Anne Greenleaf, Milli Lake, and Jennifer Noveck. "Building Capacity, Building Rights? State Capacity and Labor Rights in Developing Countries." World Development 72 (2015):127-39.

Bhattacharya, Himika. "Performing Silence: Gender, Violence, Resistance in Women's Narratives." Qualitative Inquiry 15 (2009): 359-71.

Biswas, Soutik. "India's 'Pink' Vigilante Women.” BBC News (2007).

Blackstone, Amy, Christopher Uggen, and Heather McLaughlin. "Legal Consciousness and Responses to Sexual Harassment." Law $\mathcal{B}$ Society Review 43, no. 3 (2009): 631-68.

BPRD. Data on Police Organizations as of January 1, 2015. Edited by Bureau of Police Research \& Development. New Delhi: Government of India, 2015.

Brass, Paul. Theft of an Idol: Text and Context in the Representation of Collective Violence. Princeton, NJ: Princeton University Press, 1997.

- The Production of Hindu-Muslim Violence in Contemporary India. Seattle: University of Washington Press, 2005.

Burton, Barbara, Nata Duvvury, Anuradha Rajan, and Nisha Varia. Domestic Violence in India, Part 2: A Summary Report of Four Records Studies. New Delhi: International Center for Research on Women, 2000.

Burton, Barbara, Anuradha Rajan, and Nandita Bhatla. Domestic Violence in India, Part 5: WomenInitiated Community Level Responses to Domestic Violence. New Delhi: International Center for Research on Women, 2002.

Caple James, Erica. Democratic Insecurities: Violence, Trauma, Intervention in Haiti. Berkeley, CA: University of California Press, 2010.

Centre for Social Research. "A Research Study on the Use and Misuse of Section 498A of the Indian Penal Code." Center for Social Research (2005): 1-5.

Chavez, Rebecca Bill. "The Construction of the Rule of Law in Argentina: A Tale of Two Provinces." Comparative Politics 35, no. 4 (2003): 417-37. doi: 10.2307/4150188

Chua, Lynette. "Pragmatic Resistance, Law, and Social Movements in Authoritarian States: The Case of Gay Collective Action in Singapore." Law EF Society Review 46, no. 4 (2012): 713-48.

Coker, Donna. "Crime Control and Feminist Law Reform in Domestic Violence Law: A Critical Review." Buffalo Criminal Law Review 4, no. 2 (2001): 801-60. doi: 10.1525/nclr.2001.4.2.801.

Commonwealth Human Rights Initiative. Seven Steps to Police Reform. New Delhi, 2010.

Corbridge, Stuart, Glyn Williams, Manoj Srivastava, and Rene Veron. Seeing the State: Governance and Governmentality in India. New York: Cambridge University Press, 2005.

Das, Veena. "Sexual Violence, Discursive Formations, and the State." Economic and Political Weekly 31, no. 35/27 (1996): 2411-2423. 
Dave, Anjali, and Gopika Solanki. "Special Cell for Women and Children: A Research Study On Domestic Violence." In Domestic Violence in India II: A Summary Report of Four Records Studies. Washington, DC: International Center for Research on Women, 2000.

Duvvury, Nata, Madhabika Nayak, and Keera Allendorf. "Links Between Masculinity and Violence." In Men, Masculinity and Domestic Violence in India. Washington, DC: International Center for Research on Women, 2002.

Engel, David, and Jaruwan Engel. Tort, Custom, and Karma: Globalization and Legal Consciousness in Thailand. Stanford, CA: Stanford University Press, 2010.

Evans, Peter. Embedded Autonomy: States and Industrial Transformation. Princeton, NJ: Princeton University Press, 2012.

Ewick, Patricia, and Susan Silbey. The Common Place of Law: Stories from Everyday Life. Chicago: University of Chicago Press, 1998.

Felstiner, William, Richard Abel, and Austin Sarat. "Emergence and Transformation of Disputes: Naming, Blaming, Claiming." Law $\mathcal{B}$ Society Review 15 (1980): 631-654.

Fisher, Talia. "Nomos without Narrative." Theoretical Inquiries in Law 9, no. 2 (2008): 473-502. doi: 10.2202/1565-3404.1194.

Fukuyama, Francis. "Transitions to the Rule of Law." Journal of Democracy 21, no. 1 (2010): 33-44. Gallagher, Mary. "Mobilizing the Law in China: "Informed Disenchantment" and the Development of Legal Consciousness." Law Ë Society Review 40 no. 4 (2006): 783-816.

Ghosh, Biswajit, and Tanima Choudhuri. "Legal Protection against Domestic Violence in India: Scope and Limitations." Journal of Family Violence 26, no. 4 (2011): 319-30.

Gibson, James L. "Truth, Reconciliation, and the Creation of a Human Rights Culture in South Africa." Law Eु Society Review 38, no. 1 (2004): 5-40.

Hansen, Thomas Blom. Wages of Violence: Naming and Identity in Postcolonial Bombay. Princeton, NJ: Princeton University Press, 2001.

. "Sovereigns Beyond the State: Legality and Authority in Urban India." In Sovereign Bodies. Edited by Thomas Blom Hansen and Finn Stepputat, 192-217. Princeton: Princeton University Press, 2009.

Hansen, Thomas Blom, and Finn Stepputat. Sovereign Bodies: Citizens, Migrants, and States in the Postcolonial World. Vol. 35. Princeton, NJ: Princeton University Press, 2005.

Hirsh, Elizabeth, and Christopher J. Lyons. "Perceiving Discrimination on the Job: Legal Consciousness, Workplace Context, and the Construction of Race Discrimination: Perceiving Discrimination on the Job." Law $\mathcal{E}$ Society Review 44, no. 2 (2010): 269-298. doi: 10.1111/j. 1540-5893.2010.00403.x.

Holston, James. Insurgent Citizenship: Disjunctions of Democracy and Modernity in Brazil. Princeton, NJ: Princeton University Press, 2008.

Holzer, Elizabeth. "What Happens to Law in a Refugee Camp?" Law $\mathcal{F}$ Society Review 47, no. 4 (2013): 837-72. doi: 10.1111/lasr.12041.

Human Rights Watch. Broken System: Dysfunction, Abuse, and Impunity in the Indian Police. New York: Human Rights Watch, 2009.

International Institute for Population Sciences. National Family Health Survey 2015-2016: India Fact Sheet. Mumbai: Government of India, Ministry of Health and Family Welfare, 2016.

—. National Family Health Survey 2015-2016: India. Mumbai: Government of India, Ministry of Health and Family Welfare, 2017.

Jaising, Indira. Men's Laws, Women's Lives. New Delhi: Women Unlimited, 2005. . "Family against Woman." Indian Express (2007).

Jerolmack, Colin, and Shamus Khan. "Talk is Cheap." Sociological Methods $\mathcal{E}$ Research 43, no. 2 (2014): 178-209.

Kannabiran, Kalpana. The Violence of Normal Times. New Delhi: Women Unlimited, 2005.

Kannabiran, Kalpana, and Ritu Menon. From Mathura to Manorama. New Delhi: Women Unlimited, 2007.

Kapur, Devesh, and Milan Vaishnav. "Strengthening Rule of Law." In Getting India Back on Track: An Action Agenda for Reform. Edited by Ashley Tellis, Bibek Debroy, and Reece Trevor. Washington, DC: Carnegie Endowment for International Peace, 2014.

Kapur, Ratna. Erotic Justice: Law and the New Politics of Postcolonialism. London: Glass House Press, 2005. 
Kaviraj, Sudipta. "On the Enchantment of the State: Indian Thought on the Role of the State in the Narrative of Modernity." European Journal of Sociology 46, no. 2 (2005): 263-96.

Khan, Shamus, and Colin Jerolmack. "Saying Meritocracy and Doing Privilege." The Sociological Quarterly 54, no. 1 (2013): 9-19.

Khilnani, Sunil. The Idea of India. New York: Farrar, Straus and Giroux, 1999.

Kishwar, Madhu. "Laws against Domestic Violence: Underused or Abused?" Manushi 28 (2003): 37-43.

Kohli, Atul. State-Directed Development: Political Power and Industrialization in the Global Periphery. New York: Cambridge University Press, 2004.

Koshyari, Shri Bhagat Singh. "Hundred and Fortieth Report on Petititon Praying for Amendments." In Section 498A of Indian Penal Code, 1860. Edited by Rajya Sabha Committee on Petitions. New Delhi: Rajya Sabha Secretariat, 2011.

Lake, Milli. "Organizing Hypocrisy: Providing Legal Accountability for Human Rights Violations in Areas of Limited Statehood." International Studies Quarterly 58, no. 3 (2014): 515-26. doi: 10. 1111 isqu. 12144.

Lazarus-Black, Mindie. Everyday Harm: Domestic Violence, Court Rites, and Cultures of Reconciliation. Chicago: University of Illinois Press, 2007.

Levine, Kay, and Virginia Mellema. "Strategizing the Street: How Law Matters in the Lives of Women in the Street-Level Drug Economy." Law Eु Social Inquiry 26, no. 1 (2001): 169-207.

Levitt, Peggy, and Sally Merry. "Vernacularization on the Ground: Local Uses of Global Women's Rights in Peru, China, India and the United States." Global Networks 9, no. 4 (2009): 441-61. doi: 10.1111/j.1471-0374.2009.00263.x.

Lodhia, Sharmila. "Legal Frankensteins and Monstrous Women: Judicial Narratives of the "Family in Crisis."” Meridians: Feminism, Race, Transnationalism 9, no. 2 (2009): 102-29.

Mahapatra, Dhananjay. "No Arrests Under Anti-Dowry Law without Magistrate's Nod: SC.” Times of India (2014).

Massoud, Mark Fathi. "Do Victims of War Need International Law? Human Rights Education Programs in Authoritarian Sudan." Law $\mathcal{F}$ Society Review 45, no. 1 (2011): 1-32. doi: 10. 1111/j.1540-5893.2011.00426.x.

—. Law's Fragile State: Colonial, Authoritarian, and Humanitarian Legacies in Sudan: Cambridge: Cambridge University Press, 2013.

McCann, Michael. "Law and Social Movements: Contemporary Perspectives." Annual Review of Law and Social Science 2 (2006): 17-38.

_. "The Unbearable Lightness of Rights: On Sociolegal Inquiry in the Global Era." Law $\mathcal{E}$ Society Review 48, no. 2 (2014): 245-73.

McCann, Michael, and Tracey March. "Law and Everyday Forms of Resistance: A Socio-Political Assessment." Studies in Law, Politics, and Society 15 (1996): 207-36.

Mendez, Juan, Guillermo O'Donnell, and Paul Pinheiro. The (Un)Rule of Law and the Underprivileged in Latin America. South Bend, IN: University of Notre Dame Press, 1999.

Merry, Sally. Getting Justice and Getting Even. Chicago: University of Chicago Press, 1990.

Moore, Erin "Gender, Power, and Legal Pluralism: Rajasthan, India." American Ethnologist 20, no. 3 (1993): 522-42.

Morrill, Calvin, Karolyn Tyson, Lauren B. Edelman, and Richard Arum. "Legal Mobilization in Schools: The Paradox of Rights and Race among Youth." Law E Society Review 44, nos. 3-4 (2010): 651-94. doi: 10.1111/j.1540-5893.2010.00419.x.

Naples, Nancy A. “A Feminist Revisiting of the Insider/Outsider Debate: The 'Outsider Phenomenon' in Rural Iowa." Qualitative Sociology 19, no. 1 (1996): 83-106. doi: 10.1007/BF02393249.

National Crime Records Bureau. Crime in India Statistics 2006. New Delhi: Government of India, Ministry of Home Affairs, 2007.

—. Crime in India 2016 Full Report. New Delhi: Government of India, Ministry of Home Affairs, 2017.

Nielsen, Laura Beth. "Situating Legal Consciousness: Experiences and Attitudes of Ordinary Citizens About Law and Street Harassment." Law EO Society Review 34, no. 4 (2000): 1055-55. doi: 10. 2307/3115131.

O'Donnell, Guillermo, and Phillippe Schmitter. Transitions from Authoritarian Rule: Tentative Conclusions from Uncertain Democracies. Baltimore: Johns Hopkins University Press, 2013. 
Panda, Pradeep, and Bina Agarwal. "Marital Violence, Human Development, Women's Property in India." World Development 33, no. 5 (2005): 823-50.

Prakash, Satya. "CJI Writes to Chief Justices on Filling 400 Vacancies in High Courts." Hindustan Times (2016).

PTI. "High Courts Cross India Short of 443 Judges as Vacancies are on the Rise." Deccan Chronicle (2016a).

_. "India Has 18 jJdges per Ten Lakh People: Law Ministry." Indian Express (2016b).

Purkayastha, Bandana, Mangala Subramaniam, Manisha Desai, and Sunita Bose. "The Study of Gender in India." Gender $\mathcal{E}$ Society 17, no. 4 (2003): 503-24.

Ranasinghe, Prashan. "The Humdrum of Legality and the Ordering of an Ethic of Care." Law $\mathbb{E}$ Society Review 48, no. 4 (2014): 709-39.

Randeria, Shalini. "Entangled Histories: Civil Society, Caste Solidarities and Legal Pluralism in Post-Colonial India." Civil Society: Berlin Perspectives 2 (2006): 213.

Rao, Sandhya, S. Indhu, Ashima Chopra, and S.N. Nagamani. "Domestic Violence: A study of Organizational Data." In Domestic Violence in India II: A Summary Report of Four Records Studies. Washington, DC: International Center for Research on Women, 2000.

Ray, Sawmya. "Legal Constructions of Domestic Violence." Sociological Bulletin (2006): 427-48.

Reynolds, Celene. "The Mobilization of Title IX Across U.S. Colleges and Universities, 1994-2014." Social Problems (2018): 1-29. doi: 10.1093/socpro/spy005.

Risse, Thomas, and Kathryn Sikkink. The Persistent Power of Human Rights: From Commitment to Compliance. Cambridge: Cambridge University Press, 2013.

Roychowdhury, Poulami. "Victims to Saviors: Governmentality and the Regendering of Citizenship in India." Gender Eु Society 29, no. 6 (2015): 792-816.

. "Desire, Rights, Entitlements: Organizational Strategies in the War on Violence." Signs: Journal of Women in Culture and Society 41, no. 4 (2016a): 793-820.

- "Over the Law: Rape and the Seduction of Popular Politics." Gender $\mathcal{E}$ Society 30, no. 1 (2016b): 80-94.

Saravade, Nandkumar. "Re-inventing the Criminal Justice System (Part 1 of 2)." March 30, 2015. Available at https://www.linkedin.com/pulse/reinventing-criminal-justice-system-part-12-nandkumar-saravade.

Sen, Rukmini. "Women's Subjectivities of Suffering and Legal Rhetoric on Domestic Violence Fissures in the Two Discourses." Indian Journal of Gender Studies 17, no. 3 (2010): 375-401. doi: 10.1177/097152151001700304.

Spivak, Gayatri. "Righting Wrongs." The South Atlantic Quarterly 103, no. 2 (2004): 523-81.

Subramanian, Narendra. Nation and Family: Personal Law, Cultural Pluralism, Gendered Citizenship in India. Palo Alto, CA: Stanford University Press, 2014.

Suk, Jeannie. "Criminal Law Comes Home." Yale Law Journal 116, no. 2 (2006): 2-70.

Suneetha, A, and Vasudha Nagaraj. "Dealing with Domestic Violence towards Complicating the Rights Discourse." Indian Journal of Gender Studies 17, no. 3 (2010): 451-78.

Sunshine, Jason, and Tom Tyler. "The Role of Procedural Justice and Legitimacy in Shaping Public Support for Policing." Law EO Society Review 37, no. 3 (2003): 513-48.

Super, Gail. "Volatile Sovereignty: Governing Crime through the Community in Khayelitsha." Law $\mathbb{E}$ Society Review 50, no. 2 (2016): 450-83. doi: 10.1111/lasr.12198.

Uma, Saumya, and Vrinda Grover. Addressing Domestic Violence through the Law. New Delhi: Multiple Action Research Group, 2010.

Vaishnav, Milan. When Crime Pays: Money and Muscle in Indian Politics. New Haven: Yale University Press, 2017.

Weiss, Robert. Learning from Strangers: The Art and Method of Qualitative Interview Studies. New York: Simon and Schuster, 1995.

World Health Organization. Global and Regional Estimates of Violence Against Women: Prevalence and Health Effects of Intimate Partner Violence and Non-Partner Sexual Violence. Geneva: WHO, Department of Reproductive Health and Research, 2013.

Young, Kathryne. "Everyone Knows the Game: Legal Consciousness in the Hawaiian Cockfight." Law ES Society Review 48, no. 3 (2014): 499-530. doi: 10.1111/lasr.12094. 